\title{
Fire induced reproductive mechanisms of a Symphoricarpos (Caprifoliaceae) shrub after dormant season burning
}

\author{
John Derek Scasta ${ }^{1 *}$, David M Engle ${ }^{2}$, Ryan $\mathrm{N} \mathrm{Harr}^{3}$ and Diane M Debinski ${ }^{4}$
}

\begin{abstract}
Background: Symphoricarpos, a genus of the Caprifoliaceae family, consists of about 15 species of clonal deciduous shrubs in North America and 1 species endemic to China. In North American tallgrass prairie, Symphoricarpos orbiculatus (buckbrush) is the dominant shrub often forming large colonies via sexual and asexual reproductive mechanisms. Symphoricarpos shrubs, in particular S. orbiculatus, use a unique sexual reproductive mechanism known as layering where vertical stems droop and the tips root upon contact with the soil. Because of conflicting societal values of $\mathrm{S}$. orbiculatus for conservation and agriculture and the current attempt to restore historical fire regimes, there is a need for basic research on the biological response of S. orbiculatus to anthropogenic burning regimes.
\end{abstract}

Results: From 2007 through 2013 we applied prescribed fires in the late dormant season on grazed pastures in the Grand River Grasslands of lowa. From 2011 to 2013, we measured how S. orbiculatus basal resprouting and layering stems were affected by patchy fires on grazed pastures, complete pasture fires on grazed pastures or fire exclusion without grazing for more than three years. We measured ramet height, ramet canopy diameter, stems per ramet, ramets per $100 \mathrm{~m}^{2}$, and probability of new layering stems 120 days after fire. Height in burned plots was lower than unburned plots but S. orbiculatus reached $\sim 84 \%$ of pre-burn height 120 days after fire. Stems per ramet were $2 x$ greater in the most recently burned plots due to basal re-sprouting. Canopy diameter and density of ramets was not affected by time since fire, but burned pastures had marginally lower densities than plots excluded from fire $(P=0.07)$. Fire triggered new layering stems and no new layering stems were found in plots excluded from fire.

Conclusions: The mechanisms of both basal sprouting and aerial layering after fire suggest S. orbiculatus is tolerant to dormant season fires. Furthermore, dormant season fires, regardless if they were patchy fires or complete pasture fires, did not result in mortality of S. orbiculatus. Dormant season fires can reduce S. orbiculatus structural dominance and maintain lower ramet densities but also trigger basal resprouting and layering.

Keywords: Disturbance; Ecology; Prairie; Rangeland; Resprout; Restoration; Woody plant

\section{Background}

Global vegetation distribution patterns are largely driven by climatic constraints and disturbance regimes (Clark 1991; Collins 2000). Grasslands on several continents were regulated by the developmental disturbances of fire, large ungulate grazing, and the synergistic interaction of the two (Fuhlendorf and Engle 2001). The vegetation composition of these fire prone grasslands includes shrubby

\footnotetext{
*Correspondence: jscasta@uwyo.edu

'Department of Ecosystem Science and Management, University of Wyoming, Laramie, WY 82071, USA

Full list of author information is available at the end of the article
}

angiosperm species that persist after fire due to vegetative regeneration mechanisms rather than recruitment (Bond and Midgley 2003). In North America, conversion to cropland and suppression of fire has rendered tallgrass prairies as one of the most threatened ecosystems globally (Sampson and Knopf 1994). Prior to European settlement, tallgrass prairie was prone to burning every three to five years (Collins 2000). Consequently, the exclusion of regular fire in the remaining tallgrass prairie alters plant succession toward a shrub dominated community and shrub encroachment is a global issue (Collins and Adams 1983; Collins 1992; Shortt and Vamosi 2012). 
Shrubs in these fire prone ecosystems utilize a resprouting life strategy that results in tradeoffs between growth and reproduction because resprouting shrubs often have smaller seeds, poor reproduction from seeds, and shortlived seed banks (Bond and Wilgen 1996; Kruger et al. 1997). The cost of energy allocation belowground to survive fire also reduces growth rate (Bond and van Wilgen 1996). Subsequently, form follows function, and resprouting species typical of disturbance prone ecosystems are multi-stemmed and short statured to optimize rapid recovery. In contrast, recruiting species are typically singlestemmed and taller, an advantage for the competition for light and dispersion of seed (Bellingham and Sparrow 2000; Bond and Midgley 2003). Researchers have focused more on seedling ecology than resprouting mechanisms as a plant life history trait, although neither regeneration strategy is mutually exclusive (Olson and Platt 1995; Higgins et al. 2000; Bond and Midgley 2003). Furthermore, basal resprouting mechanisms are not uniform within a functional group type (i.e., not all shrubs resprout basally or epicormically) or even within genera and are less understood than seedling recruitment (Enright and Goldblum 1999; Bellingham and Sparrow 2000; Ansley and Rasmussen 2005; Winter et al. 2011).

Symphoricarpos is a genus of the honeysuckle or Caprifoliaceae family, consisting of about 15 species of clonal deciduous shrubs in North America and 1 species endemic to China (S. sinensis) (Theis et al. 2008). In North America, Symphoricarpos is one of the most broadly distributed shrub genera, and $S$. orbiculatus has been described as the dominant shrub of the tallgrass prairie (Holechek et al. 2001; USDA Plant Database 2013; Scasta 2014). Asexual spread is from rhizomes and rooting of aerial stems (henceforth layering) and sexual spread is from seeds (Pelton 1953; Hullick and Manske 2006; Nesmith et al. 2006). Layering occurs when vertical stems droop horizontally and produce adventitious roots when they come into contact with the soil. While the layering mechanism has been studied from a physical disturbance standpoint, it has been largely neglected in the fire ecology literature (Hartmann and Kester 1975; Deb and Pogener 2012). Furthermore, S. orbiculatus has been characterized as a major invader of unburned prairie but the role of fire exclusion and the application of fire with livestock grazing are not well understood for this species (Bragg and Hulbert 1974; Stubbendieck et al. 2003). However, because S. orbiculatus is important for a wide range of wildlife species, there are conflicting views on the necessity and desirability of reducing S. orbiculatus (Korschgen 1962; Guthrey 1980; Brennan 1991; Soper et al. 1993; Harrell et al. 2001; Stubbendieck et al. 2003).

Quantifying S. orbiculatus reproductive mechanisms after fire will yield basic biological insights to assist managers in appropriately applying disturbance regimes and potentially develop alternative strategies to mitigate encroachment. Our objectives were to assess how $S$. orbiculatus vegetative regeneration and reproduction is affected by fire exclusion and late dormant-season fire applied every third year across entire grazed pastures or applied annually on a third of a grazed pasture. Prescribed burning in the late dormant season is the prescribed fire season most common in North American grasslands and is limited to after snow melt and before vegetation greenup. We hypothesized that $S$. orbiculatus is tolerant to dormant season burning and that the reproductive mechanisms of basal sprouting and aerial layering would be dependent on time since fire and serve as the key mechanisms of tolerance. To test our hypothesis we quantified vegetative response to prescribed fire by measuring ramet height, ramet canopy diameter, stems per ramet, ramets per $100 \mathrm{~m}^{2}$, and probability of new layering stems.

\section{Methods}

\section{Study location and design}

The study was conducted from 2011-2013 in tallgrass prairie in Ringgold County, Iowa in the Grand River Grasslands (GRG) of Iowa, USA $\left(40^{\circ} 34^{\prime} \mathrm{N}, 94^{\circ} 10^{\prime} \mathrm{W}\right)$. The GRG is in the glaciated plains of the Central Tallgrass Prairie Ecoregion and has been described as one of the premier places to restore a functioning tallgrass prairie ecosystem (Missouri Department of Conservation 2010). Annual precipitation was $968 \mathrm{~mm}$ in 2011 (+97 $\mathrm{mm}$ above long-term mean), $798 \mathrm{~mm}$ in 2012 (- $73 \mathrm{~mm}$ below longterm mean), $874 \mathrm{~mm}$ in 2013 (+3 $\mathrm{mm}$ above long-term mean and averaged $870 \mathrm{~mm}$ during the three year study (+1 $\mathrm{mm}$ above long-term mean) (Iowa Environmental Mesonet 2014). Soils are loess hills with glacial till side slopes with slopes in some areas exceeding 9\%. Subsoils have high clay content ranging from 42 to $48 \%$ and native vegetation was tallgrass prairie (USDA NRCS 2013). Herbaceous vegetation across all study pastures was dominated by perennial $\mathrm{C} 4$ graminoids (Andropogon gerardii (big bluestem), Schizacyrium scoparium (little bluestem), and Sorghastrum nutans (Indiangrass) with a component of exotic C3 graminoids and legumes (Schedonorus arundinacea (tall fescue), Bromus inermis (smooth brome), Lotus corniculatus (birdsfoot trefoil), and Trifolium spp. (clover). In these study pastures, $S$. orbiculatus was the most common shrub regardless of the spatial scale of assessment and occurred more often than any other shrub species including Rhus glabra (smooth sumac), Rosa multiflora (multiflora rose), Cornus drummondii (dogwood), Prunus spp. (plum) and Rubus spp. (raspberry) (Scasta 2014).

\section{Fire effects sampling}

Three treatments were applied and assessed: 1) Patch-burn grazing (PBG) or burning one-third of a pasture annually (the patch) with cattle having full access to the 
pasture, 2) Graze and burn (GAB) or burning pastures completely every three years with cattle having full access to the pasture, and 3) Unburned or no fire for over three years and no cattle grazing during that period. Grazing was seasonal from late-April to October with mature Angus cows. Mean ( \pm SE) size of each pasture was $27 \pm$ 3 ha and mean $( \pm \mathrm{SE})$ stocking rate was $2.3 \pm 0.2 \mathrm{AUM}$ $\mathrm{ha}^{-1}$. All prescribed fires were conducted within a four week window in the late dormant season (March 8 to April 4) prior to the emergence of S. orbiculatus leaves. Mean fire weather data for the available fires was $47 \%$ relative humidity, $9 \mathrm{~km}$ per $\mathrm{hr}$, and $18^{\circ} \mathrm{C}$. The fire and grazing treatments were in place prior to the initiation of sampling in 2011, so all patches and pastures had a consistent elapsed time since fire $(0.3,1,2$ years since fire) (Table 1$)$. The designation of 0.3 years since fire indicates that samples were measured four months after fire. We had less control over the unburned treatments and elapsed time since fire for those pastures was more than three years but the exact number of years is unknown. When we returned in 2013 to conduct a second assessment of unburned pastures, they had all either been burned or mowed so no follow up measurements were possible.

Fire effects measurements were conducted from 2011 to 2013 in six plots per pasture controlling for catena and soil type (Debinski et al. 2011). Plots were all permanent and ranged from $16 \mathrm{~m}^{2}(16 \mathrm{~m} \times 1 \mathrm{~m})$ to $350 \mathrm{~m}^{2}(25 \mathrm{~m} \times$ $14 \mathrm{~m})$. Plots were variable in size due to the variable density of $S$. orbiculatus ramets. If $S$. orbiculatus was not present within a permanent plot, we assessed $25 \mathrm{~m}$ north or south of the permanent marking pins for S. orbiculatus presence. Three additional pastures that had not been burned in more than three years were included for fire effects measurements and had three plots per pasture (Table 1). Thus, to ensure adequate sample size and in the sake of time, we sampled plots for a minimum of ten ramets to a maximum of fifty ramets in each plot. Given the clonal nature of $S$. orbiculatus and the intermingling of

Table 1 Schedule of prescribed fire and measurements of Symphoricarpos orbiculatus in the Grand River Grasslands, USA, 2007-2013

\begin{tabular}{|c|c|c|c|c|c|c|c|}
\hline \multirow[b]{2}{*}{ Treatment } & \multicolumn{7}{|l|}{ Year } \\
\hline & 2007 & 2008 & 2009 & 2010 & 2011 & 2012 & 2013 \\
\hline \multicolumn{8}{|c|}{ Patch-burn grazed pastures ( 3 pastures total delineated into 3 patches per pasture) } \\
\hline \multicolumn{8}{|l|}{ Pyland North } \\
\hline Patch A & fire & - & - & fire & $-, m_{1}, m_{2}$ &,$- m_{1}$ & fire, $m_{1}, m_{2}$ \\
\hline Patch B & - & fire & - & - & fire, $m_{1}, m_{2}$ &,$- m_{1}$ & $-, m_{1}, m_{2}$ \\
\hline Patch C & - & - & fire & - & $-, m_{1}, m_{2}$ & fire, $m_{1}$ & $-, m_{1}, m_{2}$ \\
\hline \multicolumn{8}{|l|}{ Pyland South } \\
\hline Patch A & fire & - & fire* & fire & $-, m_{1}, m_{2}$ &,$- m_{1}$ & fire, $m_{1}, m_{2}$ \\
\hline Patch B & - & fire & fire* & - & fire, $m_{1}, m_{2}$ &,$- m_{1}$ & $-, m_{1}, m_{2}$ \\
\hline Patch C & - & - & fire & - & $-m_{1}, m_{2}$ & fire, $m 1$ & $-, m_{1}, m_{2}$ \\
\hline \multicolumn{8}{|l|}{ Ringgold South } \\
\hline Patch A & fire & - & - & fire & $-, m_{1}, m_{2}$ &,$- m_{1}$ & fire, $m_{1}, m_{2}$ \\
\hline Patch B & - & fire & - & - & fire, $m_{1}, m_{2}$ &,$- m_{1}$ & $-, m_{1}, m_{2}$ \\
\hline Patch C & - & - & fire & - & $-, m_{1}, m_{2}$ & fire, $m_{1}$ & $-, m_{1}, m_{2}$ \\
\hline \multicolumn{8}{|c|}{ Graze-and-burn pastures ( 3 pastures total) } \\
\hline Gilleland & - & - & fire & - &,$- m_{1}$ & fire, $m_{1}$ &,$- m_{1}$ \\
\hline Lee Trail & - & - & fire & - &,$- m_{1}$ & fire, $m_{1}$ &,$- m_{1}$ \\
\hline Pyland West & - & - & fire & - &,$- m_{1}$ & fire, $m_{1}$ &,$- m_{1}$ \\
\hline \multicolumn{8}{|c|}{ Unburned pastures ( 3 pastures total) } \\
\hline Hog Farm & - & - & - & - & $-, m_{1}, m_{2}$ & - &,$- d$ \\
\hline Kellerton South & - & - & - & - & $-, m_{1}, m_{2}$ & - &,$- d$ \\
\hline Richardson West & - & - & - & - & $-, m_{1}, m_{2}$ & - &,$- d$ \\
\hline
\end{tabular}

Fire: $-=$ no fire; fire $=$ prescribed fire; fire ${ }^{*}=$ escaped out of the intended burn patch and burned remainder of pasture; $d=$ disrupted (we had less control over the unburned treatment and when we returned in 2013 to measure a second assessment of unburned pastures, they had all either been burned or mowed). ( $d=$ disrupted). Measurements: $m_{1}=$ Symphoricarpos orbiculatus maximum ramet height, ramet maximum canopy diameter, stems per ramet measured as number of vertical live stems arising from the same root crown; $m_{2}=$ new aerial layering stems.

Treatments: Patch-burn grazing (PBG) where one-third of a pasture (the patch) is burned and cattle have full access to the pasture, Graze and burn (GAB) where the entire pasture is burned every third year (2012 was the burn year) and cattle have full access to the pasture, and Not burned for more than three years with no grazing. Treatments were in place starting in 2007 so all patches and pastures had a consistent elapsed time since fire (0.3, 1, 2 years since fire). 
lateral vegetative structures among adjacent clones, it was not possible to distinguish individual clones (aka, genets). Therefore, we conducted measurements at the ramet level. We define ramets as individual plants or clonal fragments in the colony that are rooted and may have originated from either seed or rooted nodes from aerial layering stems that may or may not be connected to other ramets (Nesmith et al. 2006) (Figure 1). Ramet measurements were conducted approximately 120 days after fire. Maximum height of the ramet was measured as the tallest individual stem of a ramet. Maximum canopy diameter was measured as the longest horizontal axis of a ramet. Stems per ramet was measured as the total number of vertical live stems arising from the same root crown and is a reflection of the regeneration from basal resprouts. Ramets per $100 \mathrm{~m}^{2}$ were measured by noting the total number of ramets in a plot and then converting that to $100 \mathrm{~m}^{2}$, a reflection of alterations to ramet density from fire-induced mortality. New aerial layering stems were measured as vertical stems arising from the root crown but having a horizontal orientation but not yet rooting at the tip (Figure 1). All measurements for fire effects were conducted in 2011, 2012 and 2013 except presence/absence of new layering stems (Table 1). New layering stems were only identified in 2011 and 2013 in the PBG pastures and in unburned pastures in 2011 only (Table 1).

\section{Analysis}

To assess the response of $S$. orbiculatus to prescribed fires we used maximum ramet height, maximum ramet canopy

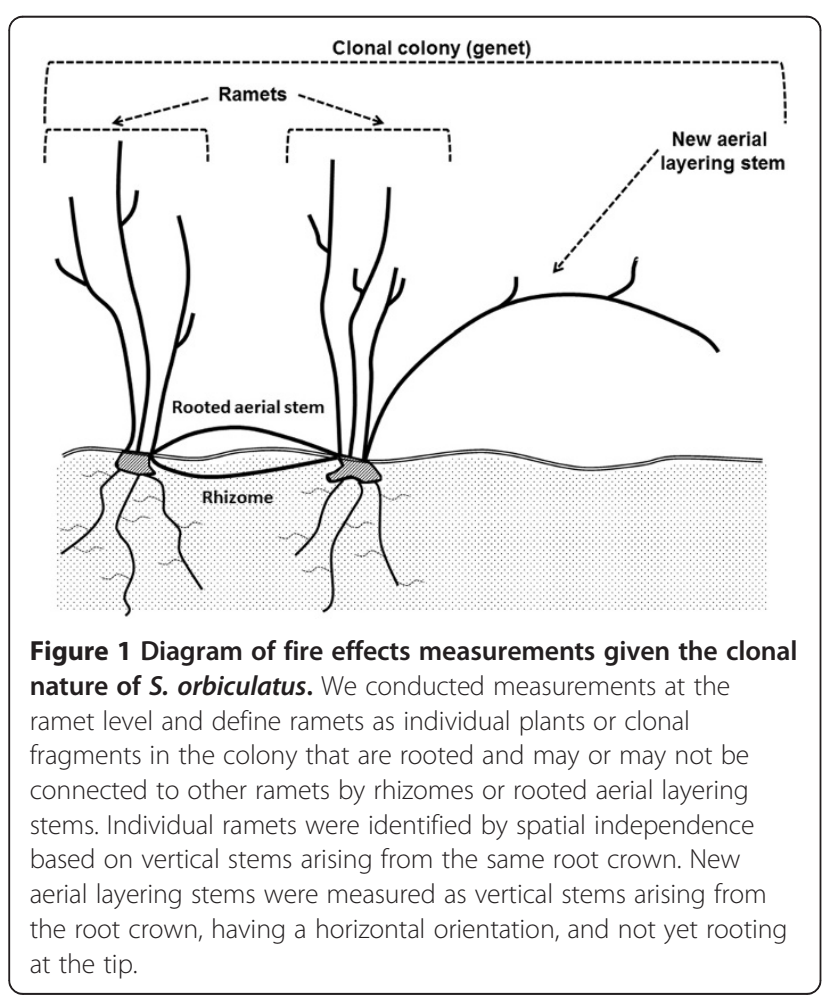

diameter and number of live stems per ramet, and density of ramets per $100 \mathrm{~m}^{2}$ as response variables. We used plot as a random effect because the plot design accounts for the highly variable topoedaphic features across the landscape, variable disturbance history associated with tillage and over grazing within and across pastures, and soil types. We also used year as a random effect because 2012 was the hottest year since 1895 (for both the mean annual high temperature and the March to May high temperature) and was the $5^{\text {th }}$ driest year since 1895 (based on Palmer's Drought Severity Index (PDSI) but 2013 was one of the wettest years since 1895 (the $81^{\text {st }}$ driest year based on PDSI) (NOAA 2014; Wang et al. 2014). We used mixed effects models (proc mixed) using the residual maximum likelihood estimation method with treatment, elapsed time since fire and the interaction between treatment and elapsed time since fire as fixed effects (SAS Institute 2011). Covariance parameter estimates for each random effect were calculated and fixed effects assessed for significance ( $\alpha$ 0.05). We then conducted post hoc least squares test for all pairwise comparisons of all combinations for fixed effects at the $95 \%$ confidence level. Binary presence/ absence data of horizontal layering stems data were used to determine odds ratios (odds $=e^{\beta \mathrm{x}}$ ) for the presence/ absence probability of layering stems related to elapsed time since fire. The logit function in proc genmod was used to model probability, assess goodness of fit and determine parameter estimate for time since fire (SAS Institute 2011).

\section{Results}

Ramet height on burned pastures, regardless of how fire was applied (henceforth, whether fire was applied PBG or GAB), was significantly lower $\left(F_{2,66}=5.47 ; P<0.01\right)$ than pastures managed without fire. Ultimately, the lower ramet height on burned pastures is largely a function of elapsed time since fire rather than how fire was applied because time since fire was positively correlated with ramet height $\left(F_{3,64}=23.66 ; P<0.01\right)$ and the two burned treatments did not differ $(P=0.32)$ (Figure 2A). The tallest $S$. orbiculatus ramets measured were $114 \mathrm{~cm}$ and were found in unburned pastures or GAB pastures 2 years after fire. Four months after fire, ramet height had reached $\sim 84 \%$ of its pre-fire height, regardless of how fire was applied.

Ramet canopy diameter did not differ between the three treatments $\left(F_{2,66}=0.09 ; P=0.92\right)$ (Figure 2B). However, the interaction between treatment and elapsed time since fire was significant $\left(F_{6,62}=4.74 ; P<0.01\right)$ as canopy diameter within PBG and GAB treatments, respectively, was lower at 0.3 years after fire than 1 or 2 years after fire (Figure $2 \mathrm{~B}$ ). The greatest ramet canopy diameter measured was $143 \mathrm{~cm}$ and was in a GAB pasture 2 years after fire. 

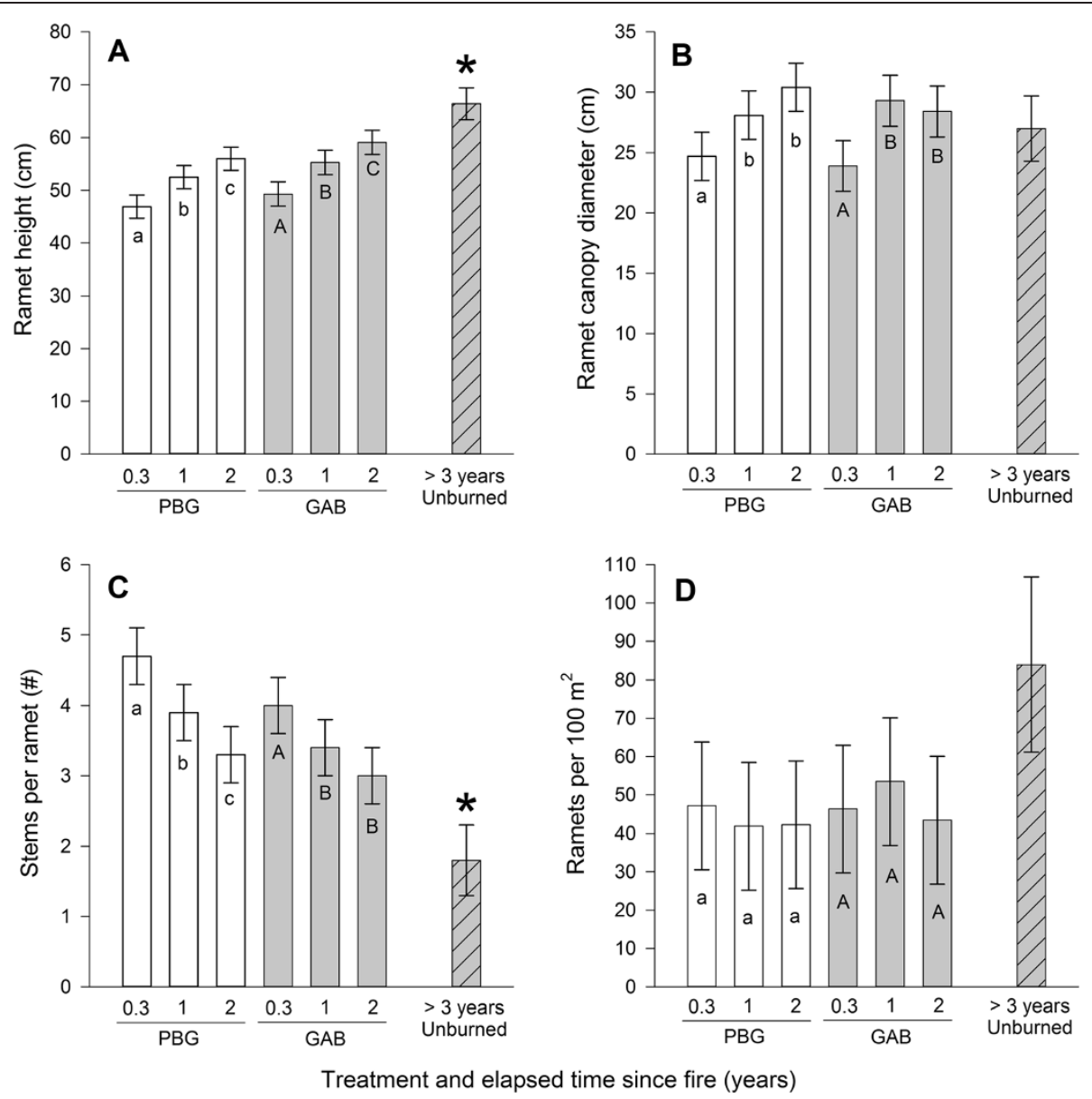

Figure 2 Mean \pm SE of ramet height (A), ramet canopy diameter (B), stems per ramet (C), and ramets per $100 \mathrm{~m}^{2}$ (D) for Symphoricarpos orbiculatus plants exposed to three fire treatments in the Grand River Grasslands of lowa, USA, 2011-2013. Treatments are 1) Patch-burn grazing (PBG) where one-third of a pasture (the patch) is burned and cattle have full access to the pasture, 2) Graze and burn (GAB) where the entire pasture is burned every third year (2012 was the burn year) and cattle have full access to the pasture, 3) Unburned for greater than three years with no grazing. The asterisk indicates if the unburned treatment is significantly different $(P \leq 0.05)$ than the burned treatments and all elapsed time since fire categories $(0.3,1$ or 2 years after fire). Letters indicate significant differences within a treatment $(P \leq 0.05)$ (lower case for PBG and capitalized for $G A B)$ based on a mixed effects model.

Ramets in the most recently burned patches in PBG pastures had 2.6 times more stems, and ramets in GAB pastures the year it was burned had 2.2 times more stems than pastures not burned in over 3 years. The number of stems per ramet on burned pastures, regardless of how fire was applied, was significantly higher $\left(F_{2,66}=\right.$ $6.39 ; P<0.01)$ than pastures not burned in over 3 years (Figure $2 \mathrm{C}$ ). Elapsed time since fire was negatively correlated with stems per ramet $\left(F_{3,64}=17.79 ; P<0.01\right)$ and the two burned treatments did not differ $(P=0.30)$ (Figure 2C). Thus, the relationship between number of stems per ramet and fire is largely a function of elapsed time since fire rather than how fire was applied.

Ramets per $100 \mathrm{~m}^{2}$ did not differ between the three treatments $\left(\mathrm{F}_{2,66}=0.03 ; P=0.30\right)$. However, the interaction between treatment and elapsed time since fire was marginally significant $\left(\mathrm{F}_{6,62}=2.04 ; P=0.07\right)$ with $\mathrm{PBG}$ and
GAB treatments displaying consistently lower densities than unburned pastures (Figure 2D). There was no apparent mortality in recently burned PBG patches or when complete GAB pastures were burned (Figure 2D).

Using logistic regression of the binomial presence/ absence of new layering stems, the parameter estimate for elapsed time since fire was -1.3 and was significant $(P<0.01)$ (Table 2). Based on the exponentiation of the parameter estimate, the odds of having a layering stem present in a plot improve 3.77 times for every year closer to the burn year. Therefore, $83 \%$ of the most recently burned patches had layering stems present with a steady decrease as time since fire elapsed. Pastures not burned in over 3 years had no new layering stems $(P<0.01)$ (Figure 3A). In a similar fashion, as time since fire elapsed, the density of layering stems per $100 \mathrm{~m}^{2}$ declines $(P<0.01)$ (Figure 3B). 
Table 2 Maximum likelihood estimates for time since fire and probability of new Symphoricarpos orbiculatus layering stems

\begin{tabular}{|c|c|c|c|c|c|}
\hline \multirow[t]{2}{*}{ Parameter } & \multirow[t]{2}{*}{ Estimate } & \multirow{2}{*}{$\begin{array}{l}\text { Standard } \\
\text { Error }\end{array}$} & \multicolumn{2}{|c|}{ Likelihood ratio $95 \%$} & \multirow[t]{2}{*}{$P$ value } \\
\hline & & & Confic & e limits & \\
\hline Intercept & 3.420 & 1.077 & 1.537 & 5.858 & 0.002 \\
\hline Time Since Fire & -1.330 & 0.403 & -2.235 & -0.622 & 0.001 \\
\hline
\end{tabular}

Maximum likelihood parameter estimates for time since fire and probability of the presence of new aerial layering stems based on the logit function and binomial presence/absence data. Based on the exponentiation of the parameter estimate, the odds of having a layering stem present improve 3.77x for every year closer to the burn year.
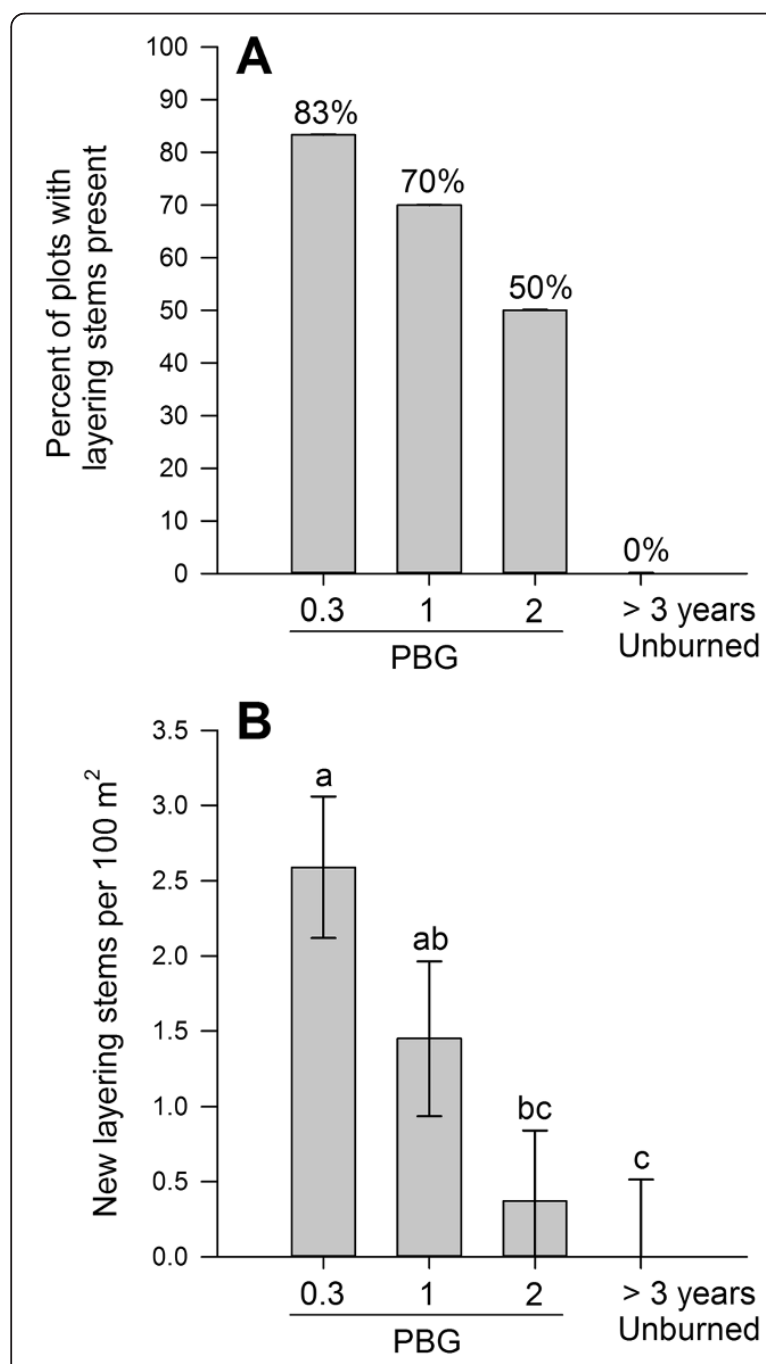

Treatment and elapsed time since fire (years)

Figure 3 Effect of elapsed time since fire on new Symphoricarpos orbiculatus horizontal layering stems based on percent of plots with new layering stems (A), and new layering stem density (B) in the unburned pastures and the Patch-burn grazed (PBG) pastures in in the Grand River Grasslands of lowa, USA, 2011 and 2013.

Letters indicate differences $(P \leq 0.05)$ based on a mixed effects model.

\section{Discussion}

Our study examining the regeneration and reproduction of $S$. orbiculatus after fire indicates that this shrub is tolerant of low-intensity prescribed fires conducted in the late dormant season or early spring prior to emergence of leaves. $S$. orbiculatus rapidly regenerated from basal resprouts, recovering to $\sim 84 \%$ of its pre-fire height 120 days after fire with no apparent mortality. S. orbiculatus used both basal resprouting and aerial layering as reproduction strategies to recover after the disturbance of fire. Ramet height increased with time since fire, but stems per ramet and aerial layering probability decreased with time since fire. Initially, fire physically altered shrub structure as measured by ramet height and stems per ramet. However, the initial structural change was only temporary as the trend indicated that as time elapses past four years, physical shrub structure becomes similar to unburned pastures, similar to Artemisia filifolia (sand sagebrush) (Winter et al. 2011).

The rapid structural regeneration of $S$. orbiculatus within the burn-year growing season is similar to other species that display rapid regrowth the first year with a declining rate of growth in the next three to four years (Gratani and Amadori 1991). The rate of recovery for $S$. orbiculatus was slower than Prosopis glandulosa (mesquite) that recovered to pre-burn heights within one year after fire (Drewa 2003). A similar study in tallgrass prairie suggested that $R$. glabra rapidly recovers to its pre-burn height and fire can result in greater plant heights than in unburned areas for both P. glandulosa and R. glabra (Drewa 2003; Hajny et al. 2011). However, fire did not appear to increase $S$. orbiculatus height in our study. In more arid environments with coarse sandy soils, A. filifolia and Quercus havardii (sand shinnery oak) recovered to only $\sim 55 \%$ of pre-burn height within the first year of a burn (Harrell et al. 2001; Winter et al. 2011). However, S. orbiculatus is similar to A. filifolia and $Q$. havardii because it took three years or more for all three species to recover to pre-burn heights. Considering these variable responses, fire only altered the physical structure of these fire-tolerant shrubs for a relatively short period, typically less than four years, and these shrubs regenerated at different rates depending on climate and soil limitations (Olson and Platt 1995; Iwasa and Kubo 1997).

Because $S$. orbiculatus seeds have little to no potential to form a long lived soil seed bank (Hidayata et al. 2001) and the rapid regeneration after fire reported herein, vegetative regeneration appears to be the primary recovery mechanism of $S$. orbiculatus to dormant season prescribed fires. In context, the tallgrass prairie is a disturbance driven ecosystem that historically had a fire return interval of three to five years (Collins 2000). The life history tradeoff between resprouting and seedling recruitment is largely 
determined by disturbance regimes and tallgrass prairie was historically disturbed regularly by fire (Wells 1969; Bellingham and Sparrow 2000; Collins 2000). Episodic resprouting events triggered by fire are followed by extended periods of self-thinning as indicated by the relationship with elapsing time since fire and declining stems per ramet in our study (Clark 1991; Hodgkinson 1998).

The low growing and multi-stemmed architecture of S. orbiculatus is also reflective of the disturbance regime of tallgrass prairie and its ability to rapidly recover after fire (Midgley 1996; Bellingham and Sparrow 2000). However, vegetative reproduction of $S$. orbiculatus after fire is not limited to basal resprouting regeneration but also appears to include aerial layering. The initiation of aerial layering has also been reported to be triggered by physical disturbances for Rubus trivialis (dewberries) from grazing, for Oplopana horridus (devil's club) from recent logging activity, and for Cercocarpus spp. (mountain mahogany) from grazing and possibly fire (Miller 1964; Abrahamson 1975; Lantz and Antos 2002). The absence of cattle grazing activity as a source of physical disturbance in the unburned pastures could also help explain the lack of new S. orbiculatus layering stems (Abrahamson 1975). In the Douglas-Fir forests of Oregon, USA, burning did not increase aerial layering but did increase basal resprouting of Acer circinatum (vine maple) while the physical disturbance of thinning and falling branches stimulated layering (O'Dea et al. 1995). However, in this old growth forest ecosystem the historic fire return interval is estimated to be 230 years compared to our study area that burned every three to five years (Agee 1993).

Our results quantifying the ability of $S$. orbiculatus to regenerate after low-intensity prescribed fires conducted in the late dormant season or early spring is similar to other Symphoricarpos species, although not every species is noted to be tolerant of fire. S. occidentalis (western snowberry) and S. albus (common snowberry) are highly tolerant to fire due to vegetative regeneration mechanisms (Mclean 1969; Anderson and Bailey 1979; Morgan and Neuenschwander 1988; Romo et al. 1993; Youngblood et al. 2006; Hauser 2007). In contrast, S. oreophilus (mountain snowberry), S. longiflorus (longflower snowberry), and $S$. mollis (creeping snowberry) have been reported to be only low to moderately resilient to fire (Bartos and Mueggler 1982; Snyder 1991; Aleksoff 1999; McWilliams 2000; McWilliams 2005; Knapp et al. 2006; Rocca 2009). Interestingly, even if a species is not highly tolerant of fire, it still may be fire dependent as S. oreophilus occurred only on burned sites (Poreda and Wullstein 1994). This variable response to fire within the genus is attributed to species distributions and biogeographic disturbance patterns because disturbance frequency is a major determinant of resprouting strength (Westman and O’Leary 1986; USDA Plant Database 2013).
In contrast to our study, other studies have reported reductions in S. orbiculatus with fire. Late spring burning in tallgrass prairie reduced $S$. orbiculatus due to lower carbohydrate reserves because plants had already leafed out (Hulbert 1984) which is different than our early spring burns and no apparent reductions. Furthermore, two successive years of spring burning in April in a forested corridor of Kansas reduced S. orbiculatus canopy cover from $40 \%$ to $9 \%$ but did not alter shrub species richness (Abrams 1988). Thus, burning later in the season or burning a site repeatedly for successive years may result in reductions of S. orbiculatus. However, at our research sites, most burning is done in the early spring and may not be possible in late spring due to Schedonorus arundinaceus (tall fescue) greenup and alteration of fire behavior (McGranahan et al. 2012). Furthermore, it can be difficult to graze and burn complete pastures for successive years (Ansley et al. 2010).

Woody plant encroachment in mesic grasslands was regulated by fire (Pyne 1997; Briggs et al. 2005). However, fire has largely been removed from the landscape or is only applied in a short seasonal window in the latedormant season leading to the need for herbicide treatments (Smith 1977; Defelice 1991; Stubbendieck et al. 2003). It is important to consider that historically wildland fire seasonality, intensity and frequency may have been very different than conventional applications of prescribed fire. Our study suggests that a three-year fire return interval using dormant season prescribed fires does not result in plant mortality but can result in altered physical structure and could maintain lower densities of S. orbiculatus. While our study did not document mortality, this is a common result for resprouting shrubs (Canadell et al. 1991; Olson and Platt 1995). However, we did document lower densities on pastures managed with regular fire compared to higher densities on pastures managed with long-term fire exclusion but the stimulation of aerial layering by fire could theoretically increase density. This contradiction needs additional research across greater temporal scales. Furthermore, unlike other shrub species such as $R$. glabra that may increase with fire, S. orbiculatus density and expansion appears to be hindered by regular fire but further research is needed on other seasonal applications and intensities of fire (Hajny et al. 2011).

Our study also included the spatio-temporal application of patchy fires (PBG) and cattle grazing, an attempt to recouple pre-settlement fire and grazing processes (Burrows 1991; Fuhlendorf and Engle 2001). The attraction to recently burned patches alters grazing patterns and results in fuel accumulation in long-unburned patches and potentially enhances fire behavior (Kerby et al. 2007). However, when compared to attempting to burn a pasture completely, we did not observe different vegetative responses associated with fire intensity or herbivory. This is 
not surprising because $S$. orbiculatus is an extremely effective resprouter after fire and cattle do not graze $S$. orbiculatus (Stubbendieck et al. 2003).

\section{Conclusion}

Our documentation of fire triggering aerial layering of $S$. orbiculatus is a new insight relevant to fire-prone mesic grasslands. Other studies have documented physical stimulation of aerial layering for other species in less fireprone ecosystems or for horticultural purposes (Hartmann and Kester 1975; O'Dea et al. 1995; Lantz and Antos 2002; Deb and Pogener 2012). As woody plants continue to encroach and transition these critical areas for conservation from grasslands to shrublands, it is increasingly critical that we continue to understand the organismal communities and ecological drivers (Samson 2004; Briggs et al. 2005; Zhang and Zhang 2007). We suggest that aerial layering be considered as an adaptation to fire disturbances and that additional research is warranted. Areas for additional inquiry include how aerial layering and seed production of $S$. orbiculatus fluctuate along a gradient of disturbance and how fire intensity and fire return interval affect belowground total non-structural carbohydrate reserves because modern anthropogenic fire regimes may not replicate a natural lighting-ignited fire regime (Kennedy and Potgieter 2003; de Groot and Wein 2004). Finally, it is also important to understand how this basic plant ecology information applies to other resprouting shrub species that use a layering mechanism and how spatially heterogeneous prescribed burning functions in land management and conservation (Hodgkinson 1998; Doumas and Koprowski 2012).

\section{Abbreviations \\ AUM: Animal unit month; GAB: Graze and burn treatment; GRG: Grand River Grasslands; NOAA: National Oceanic, and Atmospheric Administration; PBG: Patch-burn grazing treatment; PDSI: Palmer's Drought Severity Index; USDA: United States Department of Agriculture.}

\section{Competing interests}

The authors declare that they have no competing interests.

\section{Author's information}

JDS conducted the sampling portion of this project while a graduate student at Oklahoma State University.

\section{Authors' contributions}

JDS designed the shrub measurement protocol, conducted all sampling and statistical analyses. DME and DMD designed the overarching fire and grazing treatments. RNH served as the fire boss for all prescribed burning activities and established the permanent plots. All authors wrote and revised the manuscript and have read and approved the final manuscript.

\section{Acknowledgements}

This research was supported by the Oklahoma Agricultural Experiment Station, lowa Department of Natural Resources (DNR), lowa Agricultural and Home Economics Experiment Station, and the lowa State Wildlife Grants program grant \#-U-2-R-1 in cooperation with the U.S. Fish and Wildlife Service, Wildlife and Sport Fish Restoration Program (\#-U-2-R-1). Appreciation is extended to Josh Rusk and Shannon Rusk for support of field activities and coordination of treatments. We also extend appreciation to the many graduate students, staff and faculty that conducted the 27 prescribed fires over the course of this project.

\section{Author details}

${ }^{1}$ Department of Ecosystem Science and Management, University of Wyoming, Laramie, WY 82071, USA. ${ }^{2}$ Department of Natural Resource Ecology and Management, Oklahoma State University, Stillwater, OK, USA. ${ }^{3}$ lowa Department of Natural Resources, Des Moines, IA, USA. ${ }^{4}$ Department of Ecology, Evolution, and Organismal Biology, lowa State University, Ames, IA, USA.

Received: 27 October 2014 Accepted: 9 December 2014 Published online: 24 December 2014

\section{References}

Abrahamson WG (1975) Reproductive strategies in dewberries. Ecology 56:721-726, doi:10.2307/1935508

Abrams MD (1988) Effects of prescribed fire on woody vegetation in a gallery forest understory in northeastern Kansas. Trans Kans Acad Sci 91:63-70

Agee JK (1993) Fire ecology of Pacific Northwest Forests. Island Press, Washington DC

Aleksoff KC (1999) Symphoricarpos Oreophilus. In: Fire Effects Information System. US Department of Agriculture, Forest Service, Rocky Mountain Research Station, Fire Sciences Laboratory. http://www.feis-crs.org/beta/ Accessed 30 Dec 2013

Anderson ML, Bailey AW (1979) Effect of fire on a Symphoricarpos occidentalis shrub community in central Alberta. Can J Bot 57:2819-2823, doi:10.1139/b79-334

Ansley RJ, Rasmussen GA (2005) Managing native invasive Juniper species using fire. Weed Technol 19:517-522, doi:10.1614/WT-04-098R1.1

Ansley RJ, Pinchak WE, Teague WR, Kramp BA, Jones DL, Barnett K (2010) Integrating grazing and prescribed fire restoration strategies in a mesquite savannah: II. Fire behavior and mesquite landscape cover responses. Range Ecol Manage 63:286-297, doi:10.2111/08-172.1

Bartos DL, Mueggler WF (1982) Early succession following clearcutting of aspen communities in Northern Utah. J Range Manage 35:764-768, doi:10.2307/3898260

Bellingham PJ, Sparrow AD (2000) Resprouting as a life history strategy in woody plant communities. Oikos 89:409-416, doi:10.1034/j.1600-0706.2000.890224.x

Bond WJ, Midgley JJ (2003) The evolutionary ecology of sprouting in woody plants. Int J Plant Sci 164:S103-S114, doi:10.1086/374191

Bond WJ, Van Wilgen BW (1996) Fire and plants, Population and Community Biology Series 14. Springer, Netherlands

Bragg TB, Hulbert LC (1974) Woody plant invasion of unburned Kansas bluestem prairie. J Range Manage 29:19-23, doi:10.2307/3897682

Brennan LA (1991) How can we reverse the northern bobwhite population decline? Wildlife Soc B 19:544-555

Briggs JM, Knapp AK, Blair JM, Heisler JL, Hoch GA, Lett MS, McCarron JK (2005) An ecosystem in transition: causes and consequences of the conversion of mesic grassland to shrubland. Bioscience 55:243-254, doi:10.1641/0006-3568 (2005)055[0243:AEITCA]2.0.CO;2

Burrows ND (1991) Patch-burning desert nature reserves in Western Australia using aircraft. Int J Wildl Fire 1:49-55

Canadell J, Lloret F, López-Soria L (1991) Resprouting vigour of two Mediterranean shrub species after experimental fire treatments. Vegetatio 95:119-126, doi:10.1007/BF00045210

Clark JS (1991) Disturbance and tree life history on the shifting mosaic landscape. Ecology 72:1102-1118, doi:10.2307/1940609

Collins SL (1992) Fire frequency and community heterogeneity in tallgrass prairie vegetation. Ecology 73:2001-2006, doi:10.2307/1941450

Collins SL (2000) Disturbance frequency and community stability in native tallgrass prairie. Amer Nat 155:311-325, doi:10.1086/303326

Collins SL, Adams DE (1983) Succession in grasslands. Thirty-two years of change in a central Oklahoma tallgrass prairie. Vegetatio 51:181-190, doi:10.1007/BF00129437

de Groot WJ, Wein RW (2004) Effects of fire severity and season of burn on Betula glandulosa growth dynamics. Int J Wildland Fire 13:287-295, doi:10.1071/WF03048

Deb CR, Pongener A (2012) Studies on the in vitro regenerative competence of aerial roots of two horticultural important Cymbidium species. J Plant Biochem Biot 21:235-241, doi:10.1007/s13562-011-0099-5 
Debinski DM, Moranz RA, Delaney JR, Miller JR, Engle DM, Winkler LB, McGranahan DA, Barney RJ, Trager JC, Stephenson AL, Gillespie MK (2011) A cross-taxonomic comparison of insect responses to grassland management and land-use legacies. Ecosphere 2:1-16, doi:10.1890/ES11-00226.1

Defelice MS (1991) Buckbrush (Symphoricarpos orbiculatus) control in tall fescue (Festuca arundinacea) pastures. Weed Technol 5:841-844

Doumas SL, Koprowski JL (2012) Effect of heterogeneity in burn severity on Mexican fox squirrels following the return of fire. Int I Wildland Fire 22:405-413, doi:10.1071/WF12046

Drewa PB (2003) Effects of fire season and intensity on Prosopis glandulosa Torr. var. glandulosa. Int J Wildland Fire 12:147-157, doi:10.1071/WF02021

Enright NJ, Goldblum D (1999) Demography of a non-sprouting and resprouting Hakea species (Proteaceae) in fire-prone Eucalyptus woodlands of southeastern Australia in relation to stand age, drought and disease. Plant Ecol 144:71-82, doi:10.1023/A:1009839800864

Fuhlendorf SD, Engle DM (2001) Restoring heterogeneity on rangelands: ecosystem management based on evolutionary grazing patterns. Bioscience 51:625-632, doi:10.1641/0006-3568(2001)051 [0625:RHOREM]2.0.CO;2

Gratani L, Amadori M (1991) Post-fire resprouting of shrubby species in Mediterranean maquis. Vegetatio 96:137-143, doi:10.1007/BF00044975

Guthery FS (1980) Bobwhites and brush control. Rangelands 2:202-204

Hajny KM, Hartnett DC, Wilson GW (2011) Rhus glabra response to season and intensity of fire in tallgrass prairie. Int J Wildland Fire 20:709-720 doi:10.1071/WF09127

Harrell WC, Fuhlendorf SD, Bidwell TG (2001) Effects of prescribed fire on sand shinnery oak communities. J Range Manage 54:685-690, doi:10.2307/4003672

Hartmann HT, Kester DE (1975) Plant Propagation: Principles and Practices, 3rd edn. Prentice-Hall, New Jersey

Hauser AS (2007) Symphoricarpos Occidentalis. In: Fire Effects Information System. US Department of Agriculture, Forest Service, Rocky Mountain Research Station, Fire Sciences Laboratory. http://www.feis-crs.org/beta/ Accessed 30 Dec 2013

Hidayati SN, Basakin JM, Baskin CC (2001) Dormancy-breaking and germination requirements for seeds of Symphoricarpos orbiculatus (Caprifoliaceae). Am J Bot 88:1444-1451, doi:10.2307/3558452

Higgins SI, Pickett ST, Bond WJ (2000) Predicting extinction risks for plants: environmental stochasticity can save declining populations. Trends Ecol Evol 15:516-520, doi:10.1016/S0169-5347(00)01993-5

Hodgkinson KC (1998) Sprouting success of shrubs after fire: height-dependent relationships for different strategies. Oecologia 115:64-72, doi:10.1007/s004420050492

Holechek JL, Pieper RD, Herbel CH (2001) Range Management: Principles and Practices, 4th edn. Prentice-Hall, New Jersey

Hulbert LC (1984) Fire effects on tallgrass prairie. In: Proceedings of the $9^{\text {th }}$ North American Prairie Conference. Moorehead University, Moorehead

Hullick CJ, Manske LL (2006) Evaluation of Western Snowberry Management Practices: A Study and Demonstration. In: North Dakota State University Archives. http://www. ag.ndsu.edu/archive/dickinso/research/2005/range05f.htm Accessed 30 Apr 2014

SAS Institute (2011) SAS data integration studio 4.3: user's guide. SAS institute, North Carolina

lowa Environmental Mesonet (2014) IEM climodat for Mt. Ayr. In: lowa Mesonet Station, lowa State University. http://mesonet.agron.iastate.edu/climodat/ Accessed 20 Feb 2014

Iwasa YOH, Kubo T (1997) Optimal size of storage for recovery after unpredictable disturbances. Evol Ecol 11:41-65, doi:10.1023/A:1018483429029

Kennedy AD, Potgieter ALF (2003) Fire season affects size and architecture of Colophospermum mopane in southern African savannas. Plant Ecol 167:179-192, doi:10.1023/A:1023964815201

Kerby JD, Fuhlendorf SD, Engle DM (2007) Landscape heterogeneity and fire behavior: scale-dependent feedback between fire and grazing processes. Landscape Ecol 22:507-516, doi:10.1007/s10980-006-9039-5

Knapp EE, Schwilk DW, Kane JM, Keeley JE (2006) Role of burning season on initial understory vegetation response to prescribed fire in a mixed conifer forest. Can J Forest Res 37:11-22, doi:10.1139/×06-200

Korschgen $\sqcup$ (1962) Foods of Missouri deer, with some management implications. J Wild life Manage 26:164-172, doi:10.2307/3798598

Kruger LM, Midgley JJ, Cowling RM (1997) Resprouters vs reseeders in South African forest trees; a model based on forest canopy height. Funct Ecol 11:101-105, doi:10.1046/j.1365-2435.1997.00064.x

Lantz TC, Antos JA (2002) Clonal expansion in the deciduous understory shrub, devil's club (Oplopanax horridus; Araliaceae). Can J Bot 80:1052-1062, doi:10.1139/b02-095
McGranahan DA, Engle DM, Fuhlendorf SD, Miller JR, Debinski DM (2012) An invasive cool-season grass complicates prescribed fire management in a native warm-season grassland. Nat Area J 32:208-214, doi:10.3375/043.032.0214

McLean A (1969) Fire resistance of forest species as influenced by root systems. J Range Manage 22:120-122, doi:10.2307/3896195

McWilliams J (2000) Symphoricarpos albus. In: Fire Effects Information System. US Department of Agriculture, Forest Service, Rocky Mountain Research Station, Fire Sciences Laboratory. http://www.feis-crs.org/beta/ Accessed 30 December 2013

McWilliams JD (2005) Symphoricarpos Longiflorus. In: Fire Effects Information System. US Department of Agriculture, Forest Service, Rocky Mountain Research Station, Fire Sciences Laboratory. http://www.feis-crs.org/beta/ Accessed 30 Dec 2013

Midgley JJ (1996) Why the world's vegetation is not totally dominated by resprouting plants; because resprouters are shorter than reseeders. Ecography 19:92-95, doi:10.1111/j.1600-0587.1996.tb00159.x

Miller WB (1964) An Ecological Study of the Mountain Mahogany Community. Laramie: Thesis, University of Wyoming.

Missouri Department of Conservation (2010) Grand River Grasslands, Conservation Opportunity Area. In: Missouri Department of Conservation Wildlife Division. http://mdc.mo.gov/node/9822 Accessed 30 Dec 2013

Morgan P, Neuenschwander LF (1988) Seed-bank contributions to regeneration of shrub species after clear-cutting and burning. Can J Bot 66:169-172, doi:10.1139/b88-026

Nesmith JC, Hibbs DE, Shatford JP (2006) Clonal growth patterns of creeping snowberry (Symphoricarpos hesperius GN Jones) and trailing blackberry (Rubus ursinus Cham. and Schlecht) in the western foothills of the Cascade Mountains, Oregon. Northwest Sci 80:274-282

NOAA (2014) Climate at a Glance, Time Series. In: National Climatic Data Center, National Oceanic, and Atmospheric Administration. www.ncdc.noaa.gov/cag/ Accessed 29 Sep 2014

O'Dea ME, Zasada JC, Tappeiner JC (1995) Vine maple clone growth and reproduction in managed and unmanaged coastal Oregon Douglas-fir forests. Ecol Appl 5:63-73, doi:10.2307/1942052

Olson MS, Platt WJ (1995) Effects of habitat and growing season fires on resprouting of shrubs in longleaf pine savannas. Vegetatio 119:101-118, doi:10.1007/BF00045593

Pelton J (1953) Studies on the life-history of Symphoricarpos occidentalis Hook., in Minnesota. Ecol Monogr 23:17-39, doi:10.2307/1943518

USDA Plant Database (2013) Symphoricarpos orbiculatus. In: US Department of Agriculture. https://plants.usda.gov/core/profile?symbol=SYOR Accessed 30 Apr 2014

Poreda SF, Wullstein LH (1994) Vegetation recovery following fire in an oakbrush vegetation mosaic. West $N$ Am Nat 54:380-383

Pyne SJ (1997) America's Fires. Forest History Society, Durham

Rocca ME (2009) Fine-scale patchiness in fuel load can influence initial post-fire understory composition in a mixed conifer forest, Sequoia National Park, California. Nat Area J 29:126-132, doi:10.3375/043.029.0204

Romo JT, Grilz PL, Redmann RE, Driver EA (1993) Standing crop, biomass allocation patterns and soil-plant water relations in Symphoricarpos occidentalis Hook. following autumn or spring burning. Am Midl Nat 130:106-115, doi:10.2307/2426279

Samson F, Knopf F (1994) Prairie conservation in North America. Bioscience 44:418-421, doi:10.2307/1312365

Samson FB, Knopf FL, Ostlie WR (2004) Great Plains ecosystems: past, present, and future. Wildlife Soc B 32:6-15, doi:10.2193/0091-7648(2004)32[6:GPEPPA] 2.0.CO; 2

Scasta JD (2014) Implications of Pyric Herbivory For Grassland Ecology, Management and Production. Stillwater: Dissertation, Oklahoma State University.

Shortt KB, Vamosi SM (2012) A review of the biology of the weedy Siberian peashrub Caragana arborescens, with an emphasis on its potential effects in North America. Bot Stud 53:1-8

Smith L (1977) The Allelopathic Potential of Symphoricarpos orbiculatus in the Kansas Tall Grass Prairie. Emporia: Thesis, Emporia State University.

Snyder SA (1991) Symphoricarpos mollis. In: Fire Effects Information System. US Department of Agriculture, Forest Service, Rocky Mountain Research Station, Fire Sciences Laboratory. http://www.feis-crs.org/beta/ Accessed 30 Dec 2013

Soper RB, Lochmiller RL, Leslie DM, Engle DM (1993) Nutritional quality of browse after brush management on cross timbers rangeland. J Range Manage 46:399-410, doi:10.2307/4002657 
Stubbendieck JL, Coffin MJ, Landholt LM (2003) Weeds of the Great Plains. Nebraska Department of Agriculture Bureau of Plant Industry, Nebraska

Theis N, Donoghue MJ, Li J (2008) Phylogenetics of the Caprifolieae and Lonicera (Dipscales) based on nuclear and chloroplast DNA sequences. Syst Bot 33 (4):776-783

USDA NRCS (2013) lowa soil regions. In: US Department of Agriculture, Natural Resource Conservation Service. http://www.nrcs.usda.gov/Internet/ FSE_DOCUMENTS/nrcs142p2_006361.pdf Accessed 30 Apr 2014

Wang SYS, Barandiaran D, Hilburn K, Houser P, Oglesby B, Pan M, Pinker R, Santanello J, Schubert S, Wang H, Gillies R (2014) Could the 2012 drought in the central US have been anticipated? A review of the NASA working group research. J Earth Sci Eng 4:428-437

Wells PV (1969) The relation between mode of reproduction and extent of speciation in woody genera of the California chaparral. Evolution 23:264-267, doi: $10.2307 / 2406790$

Westman WE, O'Leary JF (1986) Measures of resilience: the response of coastal sage scrub to fire. Vegetatio 65:179-189, doi:10.1007/BF00044818

Winter SL, Fuhlendorf SD, Goad CL, Davis CA, Hickman KR, Leslie DM (2011) Fire tolerance of a resprouting Artemisia (Asteraceae) shrub. Plant Ecol 212:2085-2094, doi:10.1007/s11258-011-9975-2

Youngblood A, Metlen KL, Coe K (2006) Changes in stand structure and composition after restoration treatments in low elevation dry forests of northeastern Oregon. Forest Ecol Manag 234:143-163, doi:10.1016/j.foreco.2006.06.033

Zhang JT, Zhang F (2007) Diversity and composition of plant functional groups in mountain forests of the Lishan Nature Reserve, North China. Bot Stud 48:339-348

\section{Submit your manuscript to a SpringerOpen ${ }^{\circ}$ journal and benefit from:}

- Convenient online submission

- Rigorous peer review

- Immediate publication on acceptance

- Open access: articles freely available online

- High visibility within the field

- Retaining the copyright to your article

Submit your next manuscript at $>$ springeropen.com 